\title{
Postscript: Embers from a Global Fire
}

\author{
Jessica Moberg and Jane Skjoldli
}

Historically, the symbolic vocabulary of Charismatic Christianity is littered with fire metaphors and analogies, especially connected to the agency of the Holy Spirit. Fire can be unpredictable, like wildfire; it can be controlled, as when lighting a torch; or, it can simply go out. Drawing on such a rich symbolic tradition allows us to paint a dynamic and lively picture of Nordic Charismatic history and the contemporary scene, in which a global blaze finds its expression in more humbly burning embers. In line with these analogies, this anthology opened with the emergence of Pentecostal religiosity in the Nordic countries, tracing paths among ashes from fires that have burned brightly in the scattered sites and cities of Nordic landscapes.

Among these fires, the scholars contributing to this volume have shown how individuals and groups have tapped into, and contributed to, local, national, and global developments; torches have been passed from American revivalist movements, through religious exchanges organized by, with the help of, or as collaborations between local sites, feeding into the global blaze. As torchbearers migrated and returned, they let the

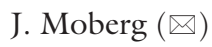

University of Gothenburg, Gothenburg, Sweden

J. Skjoldli

University of Bergen, Bergen, Norway

(C) The Author(s) 2018

J. Moberg, J. Skjoldli (eds.), Charismatic Christianity in Finland, Norway, and Sweden, Palgrave Studies in New Religions and Alternative Spiritualities, https://doi.org/10.1007/978-3-319-69614-0_10 
flames they brought with them coalesce in Nordic countries, laying the foundation for the diverse Charismatic expressions we see manifest today.

There is no one contemporary Nordic Charismatic Christianity, but many linger around the bonfires at the time of writing. Some groups have gone in a therapeutic direction, with popular music and sermon styles, and enjoy growth; their bonfires attract present lingerers. Others gather around the embers of old-fashioned Pentecostal psalms and sermons. These variations result from transformations native to the Nordic countries and internal dynamics in Charismatic bodies, as well as influences from the international, mainly Americanized Charismatic cultures.

\section{Nordic Particularities}

The chapters written by Mikaelsson and Stensvold have illustrated the strong significance of contact through transatlantic networks in the early establishment phase, in terms of national and international infrastructures of communication. Such webs of contact, including migrant networks, enabled traveling preachers to spread their message within, without, and between the Nordic countries. As shown by Mikaelsson, the role of women missionaries, previously poorly attended to in research literature, was essential to Pentecostal establishment processes.

Even though member numbers remain relatively small, this religious minority has taken up, and continues to take up space in the public spheres, including the media realm. Moreover, Charismatics have wielded media channels themselves, producing daily papers, newsletters, periodicals, TV shows, and YouTube sermons. However, despite adopting and adapting to contemporaneous mainstream trends, it seems as though the spell of peculiarity associated with this brand of Christianity has not been lifted-at least not yet.

Existing research has tended to emphasize tensions between Charismatic Christianity and national churches. Yet, as the contributions to this volume elucidate, the predominant picture of Nordic state churches as hegemonic structures is in need of nuance and problematization. While it is important to recognize their occasionally oppressive side, national churches have also benefitted Charismatic Christianity. As demonstrated by Stensvold, revivalist movements within Lutheran churches served to bridge mainstream and Charismatic Christianity. More recently, Charismatic movements within Lutheran churches have contributed to creating a new organizational base for the former. 
This book has also shed light on contemporaneous and contemporary trends in all Nordic countries, many of which have found expression in Norway, Finland, and Sweden. One of these trends regards how member recruitment has primarily taken place through socialization rather than by conversion. Another trend concerns the growth of new collaborative forms across Charismatic and non-Charismatic boundaries, pointing towards a general, but not ubiquitous pull towards ecumenism, where Charismatic discourse used to be more exclusivist. This is connected to the overall disintegration of denomination-based identities and increased mobility within the Charismatic field, in which socio-religious anchors are moved from conventional labels to the self on the one hand, and the broader revivalist scene on the other. Whereas old boundaries are deconstructed, new ones are formed around age and generation, class, and ethnic groups. As examined by Mantsinen and Alvarsson, preferential differences between generations present challenges, particularly to Pentecostal communities.

Yet another growing trend is pointed out by Hovi, Moberg, and Skjoldli, who demonstrate that Faith Movement-influenced rhetoric, strategies, practices, and theologies have given way to therapeutization, intimization, and self-censorship regarding Charismatic practices. One conspicuous aspect of this is the declining use of the previously prominent fire-laden metaphors. One might describe this new Charismatic profile as more lowkey than the earlier public profile of the Faith Movement.

\section{Nordic Issues in a Global Light}

The category of Charismatic Christianity has proven valuable for capturing historical and contemporary developments in different parts of the world. However, as the anthology clarifies, what used to be easily identifiable as "Charismatic" or "Pentecostal" in Nordic contexts has become increasingly vague and blurred by the developments sketched herein. This bears implications on how Pentecostal studies researchers construct, define, and approach their objects of study from a wider, global perspective.

Elements that were previously central to the definition of these objects seem to be losing some of their relevance, demanding the construction of categories that better capture contemporary identities, practices, alliances, and priorities. If speaking in tongues, prophecy, and healing have become marginal in several groups, how can we justify defining Charismatic Christianity based on these particular components? Still, the fact that Charismatic practices are toned down in wider collaborative situations displays consciousness 
of the social boundaries that might result from them. We believe this reflects ongoing negotiations of boundaries regarding Christian fellowship, identity, and consciousness over Charismatic primacy and uniqueness. Such developments have also been noted in the wider global Charismatic field, in which ecumenical imperatives, which used to garner suspicion, show signs of integration among Charismatics.

\section{Future Research Prospects}

Much work remains to be done in the study of Nordic Charismatic Christianity. We find three themes particularly worthy of inquiry. The first pertains to geographic coverage. Our greatest regret as editors is the lack of case studies from Denmark and Iceland. The fact that Charismatic Christianity has been relatively unsuccessful in these countries begs the question of what beneficial conditions were in place in Norway, Sweden, and Finland, that were absent in Denmark and Iceland. Second, we call for better and more nuanced statistics regarding the number of Charismatics in the Nordic region, where transdenominational aspects are considered. In this regard, we find it crucial to look at developments outside conventional denominations, in new networks and cooperative fora. Finally, Pentecostal studies would benefit from research on Charismatic movements within Nordic national churches. This "organizational embrace" of the former outsider and opponent may not only contribute to discussions about Charismatization as transformation of other denominations, but also illuminate the refashioning and possible taming of the global Charismatic fire.

Open Access This chapter is distributed under the terms of the Creative Commons Attribution 4.0 International License (http://creativecommons.org/licenses/ by $/ 4.0 /$ ), which permits use, duplication, adaptation, distribution and reproduction in any medium or format, as long as you give appropriate credit to the original author(s) and the source, provide a link to the Creative Commons license and indicate if changes were made.

The images or other third party material in this chapter are included in the chapter's Creative Commons license, unless indicated otherwise in a credit line to the material. If material is not included in the chapter's Creative Commons license and your intended use is not permitted by statutory regulation or exceeds the permitted use, you will need to obtain permission directly from the copyright holder.

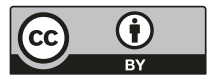

